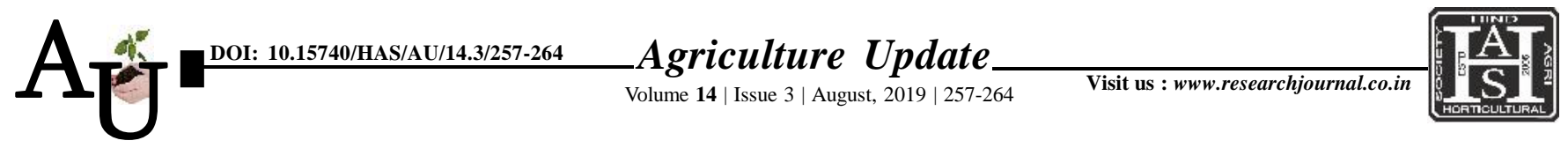

ISSN-0973-1520

\title{
acase Studx: A study on techniques of evaluating museum environment and textile artifacts
}

\author{
Shikha Bajaj and Sandeep Bains
}

Article Chronicle : Received :

01.06.2019;

Accepted :

30.07.2019

KEY WoRds:

Analysis,

Degradation,

Museum, Textile,

Sample

SUMMARY : In the past few years, museums all over the globe have started analysing contemporary approaches for integrating interactive exhibits in their premises. The stimulus has sparked the need for improved conservation techniques used for textile artifacts in any museum. Since textiles are one of the most fragile articles, these need to be attended before the spoilage starts. Fortunately, with advancements in technological field, there are a number of laboratory techniques available at this moment to identify and check the deterioration for the necessary action to be taken. The present paper not only explores various techniques and equipments used in this field while also throws light on their specific uses and applications in examining textile artifacts.

How to cite this article : Bajaj, Shikha and Bains, Sandeep (2019). A study on techniques of evaluating museum environment and textile artifacts. Agric. Update, 14(3): 257-264; DOI : 10.15740/HAS/AU/14.3/257-264. Copyright@2019: Hind Agri-Horticultural Society. 